Review

\title{
Experimental characterization of commercial lime based grouts for stone masonry consolidation
}

\author{
Eduarda Luso ${ }^{\mathrm{a}, *}$, Paulo B. Lourenço ${ }^{\mathrm{b}}$ \\ a ISISE, Polytechnic Institute of Bragança, Department of Civil Constructions, Campus Sta Apolónia, 5300-253 Bragança, Portugal \\ ${ }^{\mathrm{b}}$ ISISE, University of Minho, Department of Civil Engineering, Azurém, 4800-058 Guimarães, Portugal
}

\section{A R T I C L E I N F O}

\section{Article history:}

Received 4 February 2015

Received in revised form 17 August 2015

Accepted 16 October 2015

Available online 2 November 2015

\section{Keywords:}

Grout

Injection

Masonry

\begin{abstract}
A B S T R A C T
Conservation, repair and strengthening of historic masonry buildings should preserve their significance and ensure their structural stability. The condition of a given structure and the extent of damage determine the type of action needed. Grouting is a well-known remedial technique, which can be durable and mechanically efficient whilst preserving the historic value. Still, the selection of a grout for repair must be based on the physical and chemical properties of the existing materials. Parameters such as rheology, injectability and stability of the mix should be considered to ensure the effectiveness of grout injection. In addition, the bond strength of the grout to the existing material is the most relevant mechanical property. Several commercial lime based grouts are available but it is unclear what are the applicable standards and requirements. This paper evaluates the behavior of commercial grouts under laboratory conditions. First, the properties of the grouts as an independent product are assessed with the objective to perform a comparative analysis of their behavior subjected to different conditions (temperature and working time of grout after mixing). Then, the behavior of the grouts when used in combination with stones used in the construction of masonry buildings is addressed (granite, schist and limestone), again considering different conditions (dry, wet and saturated). It is shown that the performance of the commercial products is rather different and careful selection of injection materials in practical applications is recommended.
\end{abstract}

(c) 2015 Elsevier Ltd. All rights reserved.

\section{Contents}

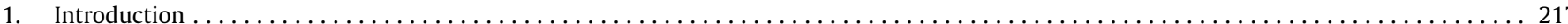

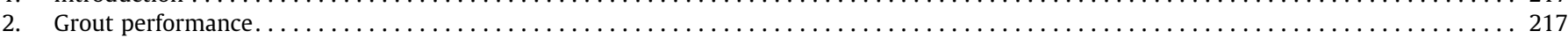

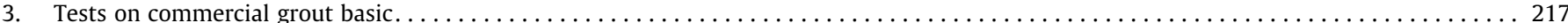

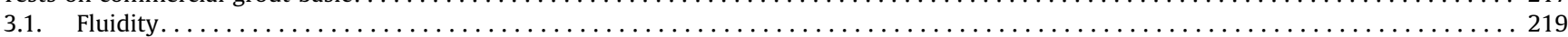

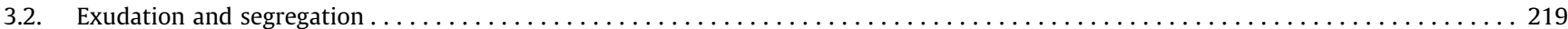

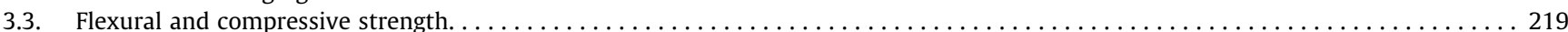

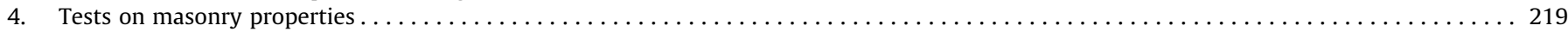

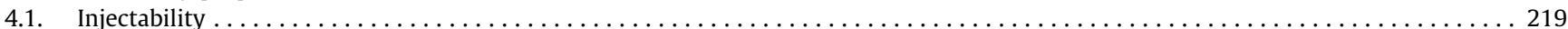

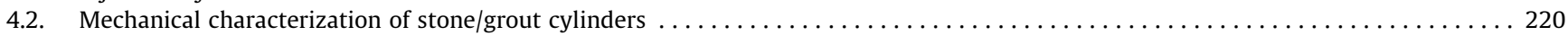

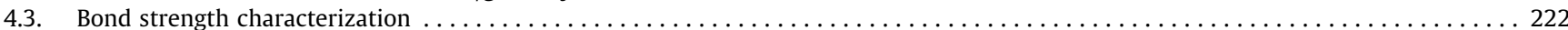

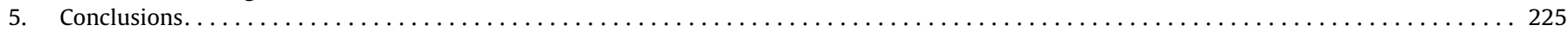

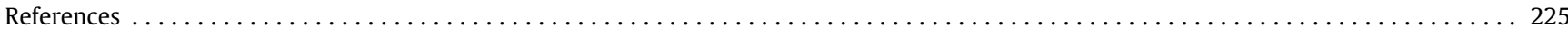

\footnotetext{
* Corresponding author.

E-mail addresses: eduarda@ipb.pt (E. Luso), pbl@civil.uminho.pt (P.B. Lourenço).
} 


\section{Introduction}

Grouting constitutes one of the most common techniques applied for the repair and strengthening of masonry structures, either in presence of voids or cracks. The technique requires that cracks and voids are interconnected to an extent that the grout can easily flow in the existing materials. This technique recovers the continuity of the existing material, providing a more homogeneous material, and increasing the cohesion and strength of the damaged structural elements, with minimal changes in their morphology and in the loadbearing system. Given that grouting is an irreversible intervention, the design of the grout as well as the method of its application to historic structures must satisfy a series of performance requirements, namely compatibility. The performance requirements involve aspects such as injectability, bond and durability, and they are set on the basis of an overall approach of the structure to be repaired, before and after intervention. The selection of grout requires information on the construction type and the dimensions of the structure, the nature of the existing materials, the nominal minimum width of voids to be filled and the distribution of voids, the possible presence of soluble salts and the desired behavior after repair.

Formulation of compatible materials for mortars or grouts to be used in conservation of ancient masonry structures is complex, due to specific requirements such as low modulus of elasticity and adequate strength, as well as the need of a physically and chemically compatible behavior with the existing materials. In the specific case of grouts for injection, the requirements are even more demanding. The complete and uniform filling of masonry voids with grout is essential in consolidation works [29] for a successful intervention. The success of this operation depends on parameters such as the distance between the injection holes, the injection pressure, the rheological properties of the grout, the water absorption capacity and the general condition of the masonry (number and width of cracks) [34].

Based on the required performance of the structure, the composition of the grout should improve the behavior of the injected system without affecting its durability. The use of lime-pozzolancement grouts seems to be one of the most attractive options [31]. Even if grout formulations remain, mostly, an empirical process, the effectiveness of ternary compositions has been proven in experimental studies in one and three leaf walls $[31,32,26,21,37]$. Alternatively, hydraulic grouts (natural hydraulic lime or cement grouts) have been proposed $[23,9,5]$. The injectability characteristics of grouts $[24,25,6]$ as well as the effect of the addition of other materials (fly ashes, silica fume, plasticizers and superplasticizers, among others) on their behavior $[10,4,22]$ have been recently studied.

Despite the fact that several formulations are proposed by different researchers, many commercial ready-mix grouts are available in the market and have been either frequently prescribed by designers or proposed by specialized companies in the area, mostly because of their easy preparation, quality control and guaranteed performance. The attractiveness of using commercial grouts mainly consists of the possibility to overcome the difficulty in formulating a suitable grout composition. Commercial grouts have been specifically formulated for this purpose, and guarantee a greater uniformity in properties and a better flow control. The preparation of these premixed grouts requires only water and no special equipment. The composition of commercial grout is varied and the description of their composition in technical data sheets is vague. Several applications of "in-situ" consolidation and laboratory tests of commercial grouts are available in the literature $[7,33,19,30]$.

If commercial grouts are used, this means that it is impossible to define specific properties for a given application and the cost of these products is usually higher than prescribed formulations. Even if these materials are used frequently, e.g. consolidation of the towers of the Cathedral of Porto in [20], very few studies have been devoted to the characterization of their effectiveness and to a comparison between different products. Technical information is usually scarce and it remains unclear which standards should be used for quality control and which requirements are applicable. Thus, the objective of the experimental program presented here is to compare the properties of commercial grouts, providing a range of properties found and alerting for the adequate selection of injection materials. Durability tests for one of the commercial grouts are available in Luso [21] but these are outside the scope of this paper and are less relevant for practical applications.

\section{Grout performance}

It is consensual that grouts to be applied in masonry walls of ancient buildings should: (i) have good bond to masonry materials such as stone or brick; (ii) have low or no shrinkage, in order not to create additional stresses, to limit the loss of adhesion between grout and existing material, and to reduce moisture penetration through shrinkage cracks; (iii) have low segregation and exudation to maintain the volume and consistency, (iv) have high fluidity and injectability, in order to provide a proper flow and to fill both large and small openings and interconnected voids, even using low pressures; (v) resist to soluble salts, possibly present in the walls, and limit the salt contents that can be transmitted to the existing material. Other properties might need to be adjusted to a given case, such as: development of strength in early days; size of the aggregates in the composition; strength and elasticity modulus; thermal expansion coefficient, among others.

The compliance with the above requirements is greatly defined by the constituting materials of the grout, namely binder(s), aggregates, water and additives. In general, a binder with water is used, without sand but possibly with some fine aggregate (filler). The design of lime-based grouts for strengthening of historic masonry buildings seems to follow rather empirical procedures, with the related uncertainties, both in terms of cost and efficiency [24]. The ingredients and the final product must be compatible with the old materials in the masonry structure being repaired but there is no test available for this parameter. Still, the chemical and mineralogical properties of the components have to be identified and an effort needs to be made to prevent any negative interaction [28].

There are no specific standards to determinate the main properties of masonry injection grouts. Normalization concerns, mostly, cement grout, mortar or concrete and the existing standards are often used only as for guidance, having to be adapted. In this paper, the workability of grouts is determined by a series of rheological tests (fluidity, stability and bleeding) used by other researchers. The injection grout is also evaluated in terms of its injectability and penetrability. The properties of the hardened material are determined by mechanical tests, namely bond, deformability and flexural and compressive strength. Recent research [31,8] has shown that tension and shear bond along interfaces between external leafs and the infill, in three leaf walls, constitute the basic mechanism of integrity and resistance of multi-leaf walls. Therefore, in the present work special attention, is given to bond between injection grout and stone substrate.

\section{Tests on commercial grout basic}

In order to verify the requirements of building materials, the usual procedure is to assess their behavior under laboratory conditions. The first phase of the experimental program described herein 
Table 1

Information available in the technical data sheet from the producers.

\begin{tabular}{|c|c|c|c|}
\hline Grout & Designation & Description & Technical data \\
\hline $\begin{array}{l}\text { Mape-Antique I, } \\
\quad \text { from Mapei }\end{array}$ & A & $\begin{array}{l}\text { Super-fluid, salt resistance, fillerized hydraulic binder, based on lime and } \\
\text { eco-pozzolan, for making injection slurries for consolidation } \\
\text { masonry }\end{array}$ & $\begin{array}{l}\text { Maximum size of aggregate (EN 1015-1): } 100 \mu \mathrm{m} \\
\text { Bulk density: } 1100 \mathrm{~kg} / \mathrm{m}^{3} \\
\text { Bleeding (NorMal M33-87)*: absent } \\
\text { Fluidity of mix (EN } 445)^{*}:<30 \text { (initial) and }<30 \text { (after } \\
60 \text { min) } \\
\text { Bulk density of fresh mortar (EN } 1015-6)^{*}: 1900 \mathrm{~kg} / \mathrm{m}^{3} \\
\text { Workability time of fresh mortar (EN } 1015-9)^{*}: \text { approx. } \\
60 \text { min } \\
\text { Compressive Strength after } 28 \text { days (EN 196-1)*: } 18 \mathrm{MPa} \\
\text { Note: }{ }^{*} \text { At } 20^{\circ} \mathrm{C} \text { and } 50 \% \text { R.H }\end{array}$ \\
\hline $\begin{array}{l}\text { Albaria Iniezione } \\
\quad \text { from } B A S F\end{array}$ & B & $\begin{array}{l}\text { It is a lime pozzolanic premixed grout without cement with a fine } \\
\text { grain (less than } 12 \mu \mathrm{m} \text { ) high fluidity and excellent workability }\end{array}$ & $\begin{array}{l}\text { Bleeding (NorMal M33-87): absent } \\
\text { Fluidity of mix, Flow cone (12.7 mm) (CRC-C } 611-80 \text { and } \\
\text { ASTM C 939): }<30 \text { (initial) and }<30 \text { (after } 60 \mathrm{~min}) \\
\text { Vapor diffusion coefficient (EN } 1745): \mu<35 \\
\text { Compressive Strength, (UNI EN 1015/11): }>10 \mathrm{MPa} \\
\text { Elasticity Modulus, (UNI EN } 13412): 6.000 \pm 10.000 \mathrm{MPa} \\
\text { Bond Strength (shear stress): }>0.15 \mathrm{MPa}\end{array}$ \\
\hline $\begin{array}{l}\text { Calce per } \\
\quad \text { Consolidamento } \\
\text { from Cepro }\end{array}$ & C & $\begin{array}{l}\text { Is a compound for structural consolidation injections on masonry } \\
\text { at low pressure }\end{array}$ & $\begin{array}{l}\text { Compressive Strength } \\
\text { At } 7 \text { days: } 1.4-4.7 \mathrm{MPa} \\
\text { At } 28 \text { days: } 2.4-7.8 \mathrm{MPa} \\
\text { At } 90 \text { days: } 1.3 \text { e } 12.5 \mathrm{MPa}\end{array}$ \\
\hline $\begin{array}{l}\text { Lime-Injection from } \\
\quad \text { Tecnochem }\end{array}$ & D & $\begin{array}{l}\text { Is a binder ideal for injection consolidation of brick masonry, or stone } \\
\text { Its hydraulic setting is fundamentally based on lime-silica micro- } \\
\text { active } \\
\text { reaction and in the presence of hydraulic lime free of harmful soluble } \\
\text { salts }\end{array}$ & $\begin{array}{l}\text { Compressive Strength at } 1 \text { day: } 0,5 \mathrm{MPa} \text { Compressive } \\
\text { Strength at } 7 \text { days: } 5 \mathrm{MPa} \\
\text { Compressive Strength at } 30 \text { days: } 10 \mathrm{MPa} \\
\text { Flexural Strength at } 30 \text { days: } 3.5 \mathrm{MPa} \\
\text { Elasticity Modulus: } 5000 \mathrm{MPa} \\
\text { Bond Strength to brick at } 60 \text { days: } 1.5 \mathrm{MPa} \\
\text { Specific surface: } 30,000 \mathrm{~cm}^{2} / \mathrm{g} \\
\text { Penetration into discontinuities of } 1 \mathrm{~mm} \text { thick: Good } \\
\text { Particle size }<20 \mu \mathrm{m}: 90 \% \\
\text { Particle size }>20 \mu \mathrm{m}: 10 \% \\
\text { Fresh density: } 1700 \mathrm{~kg} / \mathrm{l}\end{array}$ \\
\hline
\end{tabular}
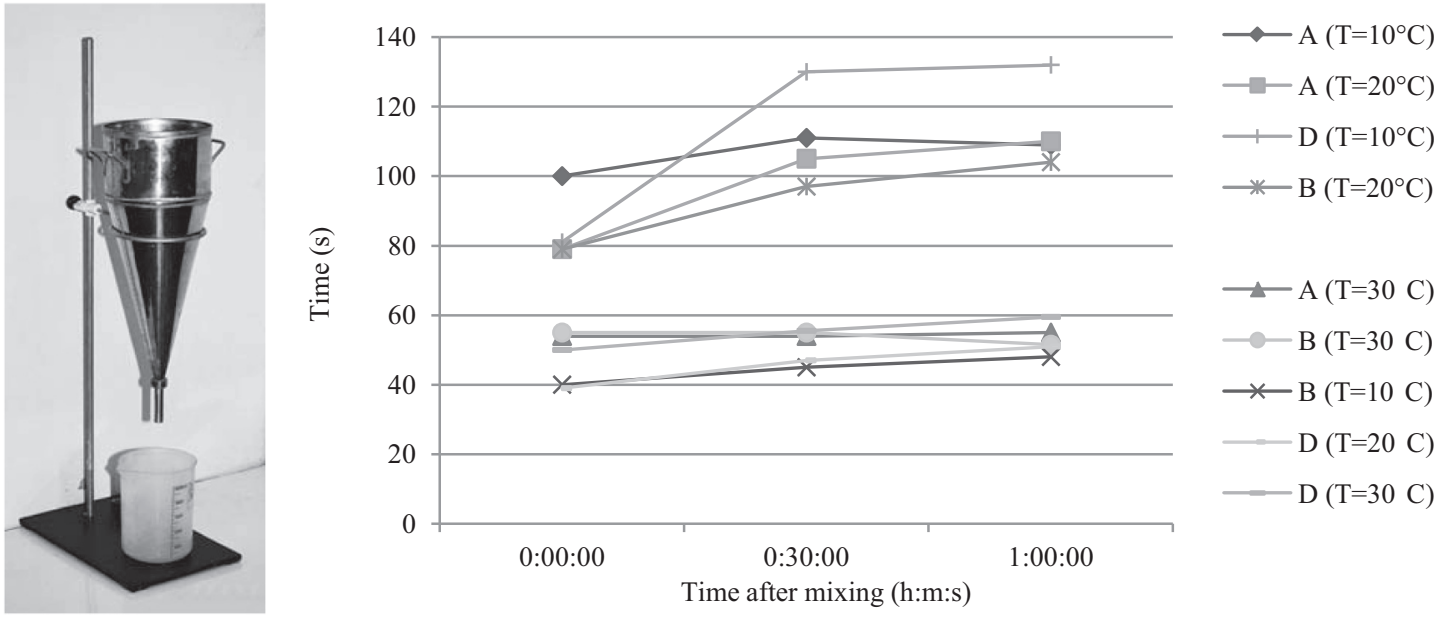

Fig. 1. Flow time for $10^{\circ} \mathrm{C}, 20^{\circ} \mathrm{C}$ and $30^{\circ} \mathrm{C}$ (water and environment).

is devoted to the characterization of commercial grouts and aims at determining the properties of the grouts independently of the substrate material, allowing to obtain a range of properties for these products. The tests considered include fluidity tests, exudation and segregation tests, and flexural and compression tests.

Commercial lime-based grouts available for use in existing masonry structures are scarce. The materials chosen in this study were: Mape-Antique I, from Mapei, Albaria Iniezione from BASF, Calce per Consolidamento from Cepro and Lime-Injection from Tecnochem. Hereafter, the grouts are designated as $A, B, C$ and $D$, respectively. The grouts were mixed using a simple mechanical mixer during
$10 \mathrm{~min}$, as it is current practice in local engineering practice. The water used for mixing the products respected the technical datasheet for each product, ranging from 0.35 for grout $A$ to $0.6-0.65$ for grout $C$.

Products $A$ and $B$ are very similar in terms of tone (light beige). Grout $D$ has a grayish color and a texture with small dark grains, which make this grout very distinct from the other materials. Finally, product $C$ is the whiter grout and is very easy to crack, in light of its rather weak strength. The description and the properties of each grout according to the respective producer, are presented in Table 1 . It is noted that the information available is rather different 
and, in some cases, incomplete, which further stresses the need to define widely accepted standards and a single procedure for product technical approval.

\subsection{Fluidity}

Fluidity is a very important property of grout, which can be directly correlated with its capacity to fill the largest possible number of voids in the interior of masonry. To determine the fluidity a test using a standardized and calibrated conical funnel dimensions (commonly known as the Marsh cone) is normally adopted. The tests measure the flow time and here six tests were carried out with each of the products, considering different values of temperature of mixing water and environment $\left(10^{\circ} \mathrm{C}, 20^{\circ} \mathrm{C}\right.$ and $\left.30^{\circ} \mathrm{C}\right)$ as well as different times between grout preparation and flow measurements $(0,30$ and $60 \mathrm{~min})$, see Fig. 1 . The values obtained showed very similar results for $A, B$ and $D$ grouts at $30^{\circ} \mathrm{C}$. Product $A$ seems to be consistently sensitive to temperature, with flow time doubling for $10^{\circ}$ and $20^{\circ} \mathrm{C}$. Products $B$ and $D$ were found to have some sensitivity to one of the temperatures. In general, products can be used up to one hour after mixing without increase in the flow time. For product $C$ it was impossible to find an average flow time for any of the temperatures used, as the flow of the grout stopped after starting the test. This means that this product cannot be used at low injection pressures.

\subsection{Exudation and segregation}

After filling a container with a mixture of water and hydrophilic binders, a layer of water will appear on the surface with a marked water-grout separation line. This separation will increase with time, at least in the initial phase of the process. In case of grout injection, this phenomenon affects the quality of the injection, because the upper part of a pore cannot be filled due to the excess of water. The tests were performed according to EN 445 [15] and ASTM C940 [3], which vary in the instant to measure exudation, namely $3 \mathrm{~h}$ and $24 \mathrm{~h}$ after mixing.

EN 447 [16] specifies that $3 \mathrm{~h}$ after the end of mixing the exudation value should be smaller than $2 \%$ of the initial volume. According to Vintzileou [36] exudation is considered excessive when it is larger than $5 \%$. All products fall within the threshold value suggested by Vintzileou [36] and EN 447 [16], see Fig. 2. Product $A$ presented the higher percentage of exudation, although within acceptable limits.

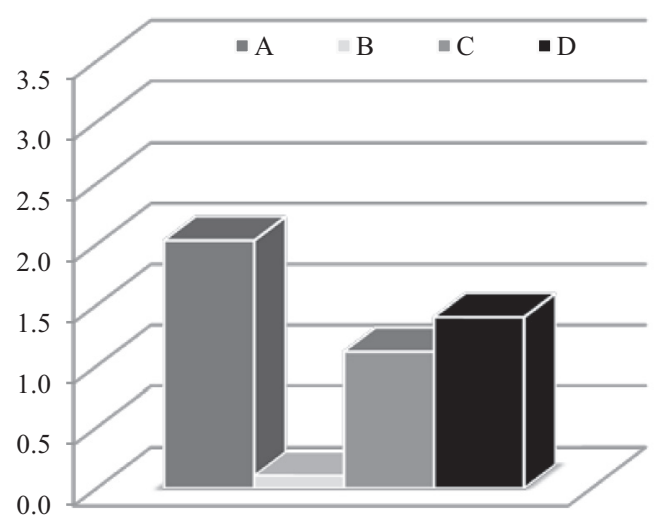

(a)

\subsection{Flexural and compressive strength}

In order to characterize the strength of the grouts, as well as the hardening evolution over time, prismatic specimens of $160 \times 40 \times 40 \mathrm{~mm}^{3}$ were molded and were tested after 28,90 , 180 and 360 days of curing, see Fig. 3.

Compressive strength of grout injection is measured for each grout on six half-specimens obtained after rupture of the original specimen during the flexural test (three tests). The test procedure adopted was in accordance with EN 445 [15], whereas, in similar investigations, [33,31] slightly adapted EN 196-1 [14] standard, used for cement mixes. In general, the compressive strength of the selected grouts increased with time. Products $A$ and $B$ exhibit higher compressive strength than $C$ and $D$. Grout $C$ presents the lowest flexural tensile strength. All strength values seem to stabilize within 180 days of curing. The maximum flexural strength value is obtained for product $A$ followed by $D$.

\section{Tests on masonry properties}

The second phase of the experimental program described herein is devoted to the characterization of commercial grouts when applied to masonry. For this purpose, three different of stones were used, namely schist (good quality hard stone), yellow granite (with some deterioration) and "moliano", a soft, limestone, which are representative samples of natural stones used in the construction of masonry buildings in Portugal. The tests considered include injectability tests, compressive and tensile strength of injected cylinders and bond strength of grout to stone.

\subsection{Injectability}

The aim of this test was to determine the performance of grout injection within different granular materials as substrate. Based on a literature review and after some preliminary tests, cylindrical acrylic molds were constructed, with a height of $300 \mathrm{~mm}$ and a diameter of $150 \mathrm{~mm}$. After filling the mold with the different granular materials, each grout was prepared with water at $20^{\circ} \mathrm{C}$ and mixed for exactly $10 \mathrm{~min}$, using the same procedure adopted in the fluidity tests. The pressure used for filling the cylinders $(0.15 \mathrm{MPa})$ was constant due to the use of an injection equipment known as "pressure pot". The time required for the complete filling of the cylinders for each commercial product used in different stones was recorded, see Fig. 4.

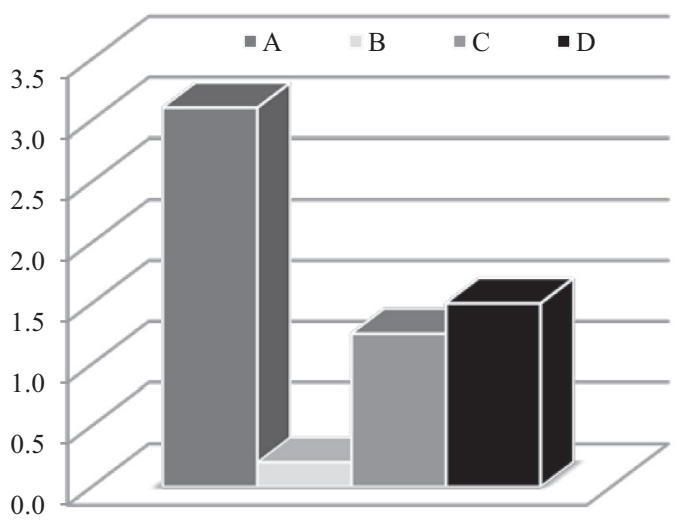

(b)

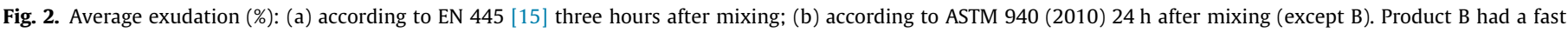
setting and the test cannot be performed. 


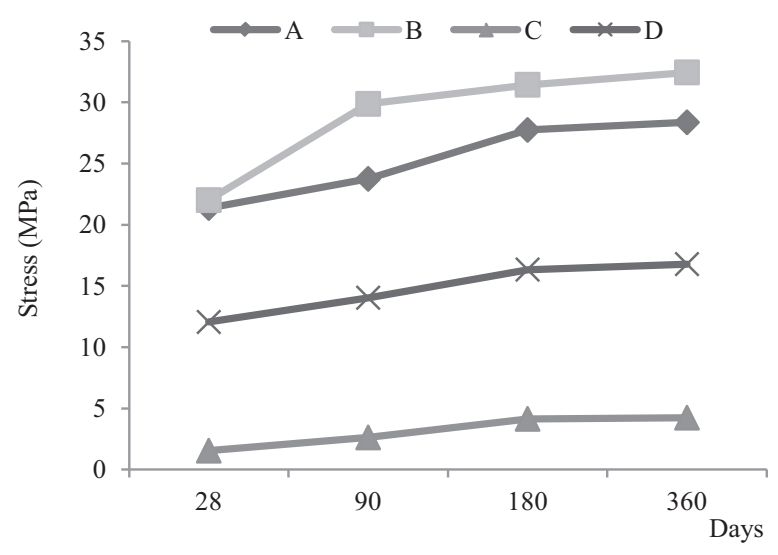

(a)

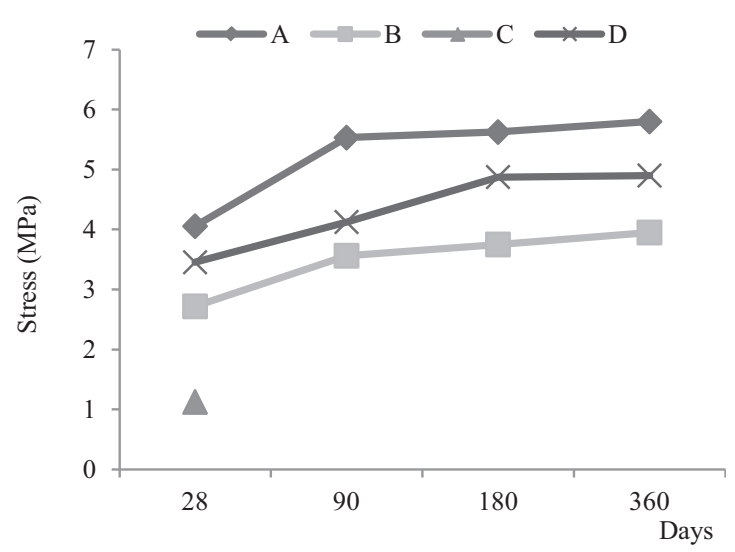

(b)

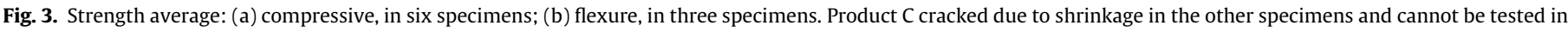
flexion.
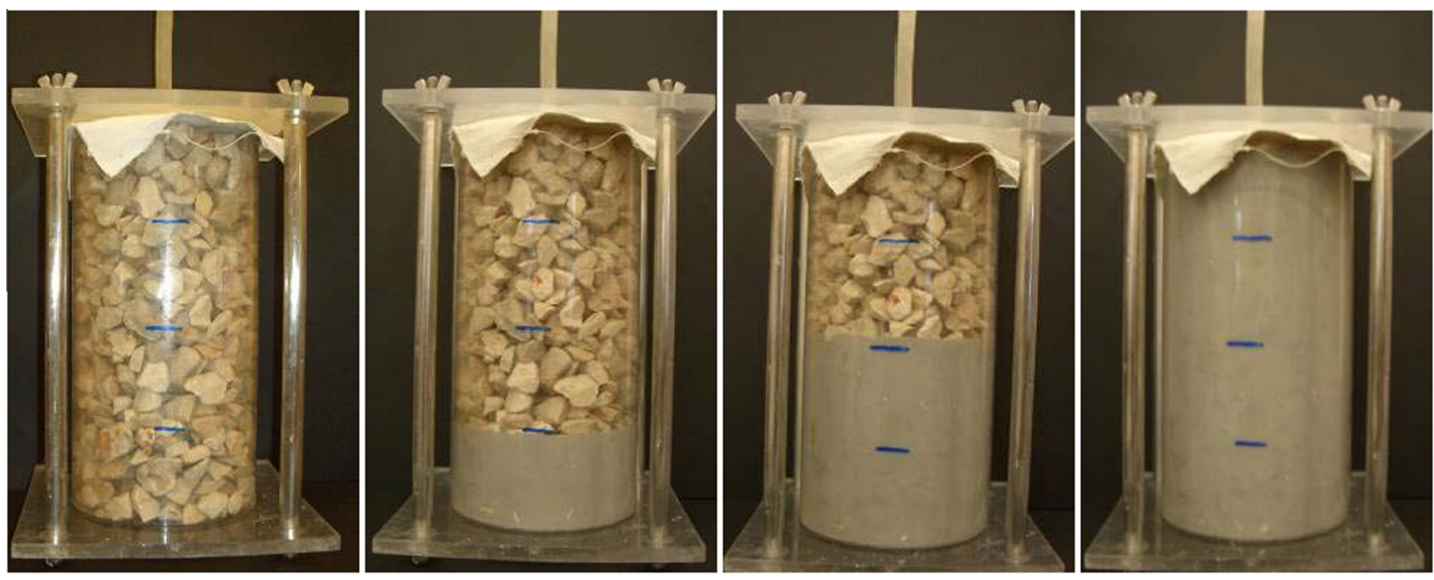

Fig. 4. Example of filling cylindrical molds (product $D$ and limestone).

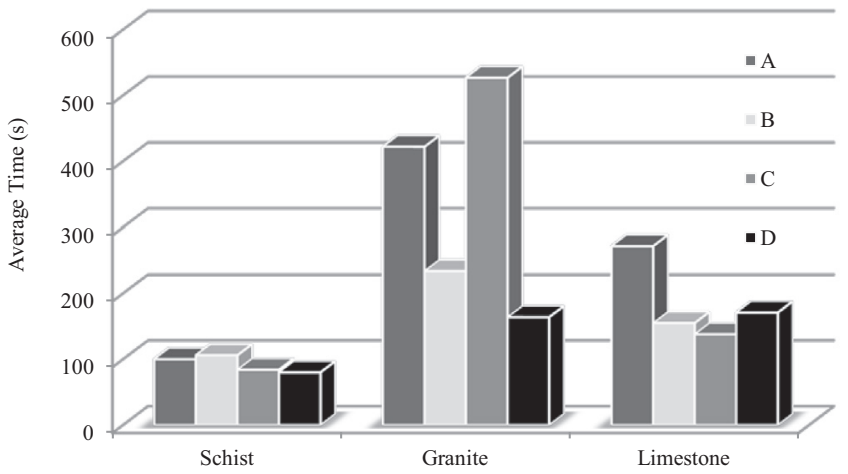

Fig. 5. Mean values of total cylindrical molds filling time.

The results of injectability tests for the commercial products are presented in Fig. 5. The graph shows the average time that each product required for the complete filling of the mold for the three stones used (schist, yellow granite and limestone) with a $50 \%$ volume of voids. It can be seen that all products gave similar performance for schist, which is a less porous material. For the deteriorated granite, products $A$ and $C$ require much larger injection times than the other two products, whereas product $A$ is also requiring far more time of injection than the rest of the products for limestone.

\subsection{Mechanical characterization of stone/grout cylinders}

After removing the molds, the cylinders described in the previous section were cured in a humid chamber during 28 and 90 days. Subsequently, uniaxial compression tests on three of the cylinders and diametrical compression tests in the other three cylinders were carried out, see Fig. 6.

The tests for compressive strength $(f c)$ were performed under control of axial displacement $(5 \mu \mathrm{m} / \mathrm{s})$, which allowed the characterization of behavior of the material after obtaining the maximum load (post peak), namely by obtaining the fracture energy ( $G f$ ) and the ductility index $(d u)$. The measurement of displacement was done using displacement transducers (LVDT's - linear variable differential transformers). To obtain the modulus of elasticity, the procedure specified by standards LNEC E 397 [12] and ASTM C469 [2] was used. The estimated values correspond to the average slope of the straight linear regression curves in the stress $\sigma$ vs. strain $\varepsilon$ diagram at each LVDT, in the last four unloading/reloading cycles. The procedure for determining the fracture energy is described by Jansen and Shah [18] and Vasconcelos [35]. This post-peak energy is spent per unit area and was obtained by integrating the stress $\sigma$ vs. displacement $\delta$ diagram, up to a post-peak ratio $\sigma / f c=1 / 3$, see Fig. 7 .

The ductility index is used to define the ductility of materials under compression, and reads: 


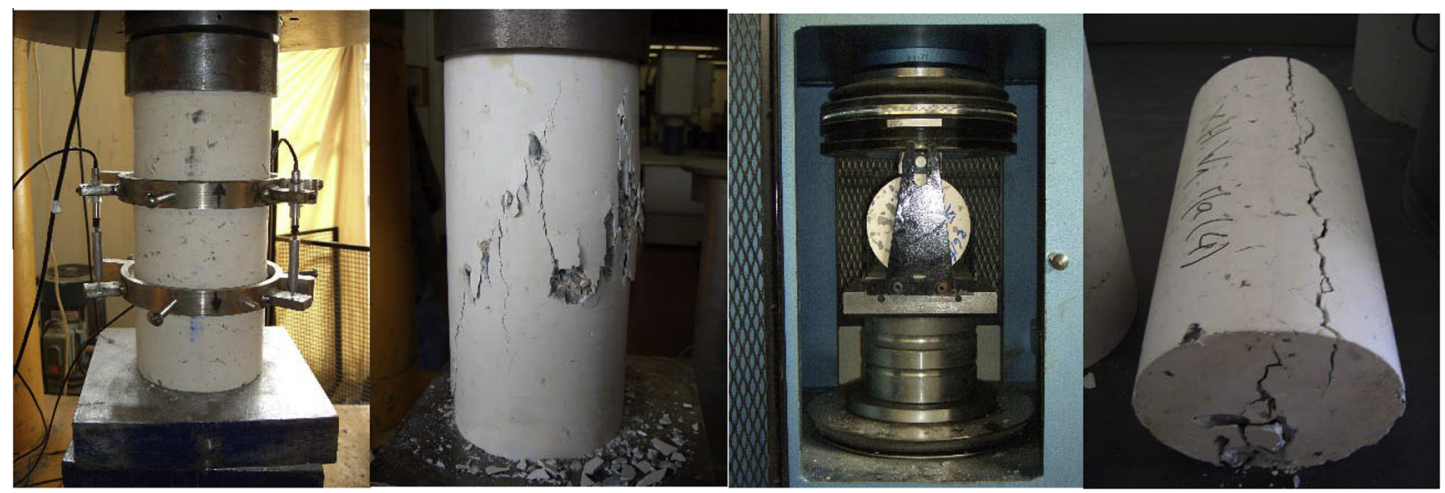

Fig. 6. Compressive and tensile tests and respectively rupture failure.

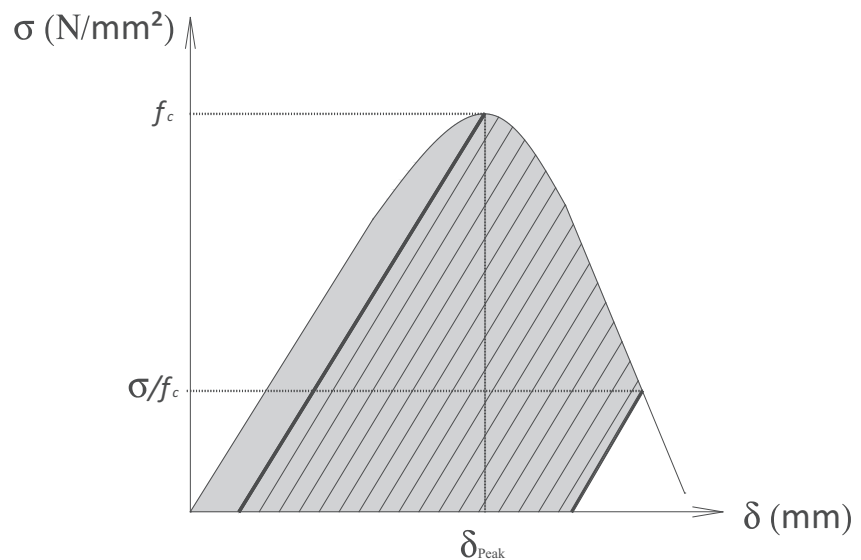

Fig. 7. Procedure used for determination of the post-peak fracture energies $[18,35]$.

Table 2

Mechanical properties of compressive tests on specimens with schist. Coefficients of variation (\%) in brackets.

\begin{tabular}{lllllll}
\hline Age & Grout & $f_{\mathrm{c}}(\mathrm{MPa})$ & $E(\mathrm{GPa})$ & $G_{f}(\mathrm{~N} / \mathrm{mm})$ & $\varepsilon_{\text {peak }}(\%)$ & $d_{u}(\mathrm{~mm})$ \\
\hline 28 & A & $14.2(2.3)$ & $17.2(5.5)$ & $30.8(2.5)$ & $0.40(2.7)$ & $2.18(0.6)$ \\
& B & $19.3(4.2)$ & $21.5(24.5)$ & $26.0(3.3)$ & $0.31(0.8)$ & $1.35(1.5)$ \\
& C & $1.9(9.4)$ & $2.1(47.6)$ & $4.0(24.1)$ & $0.42(2.84)$ & $2.00(7.6)$ \\
& D & $4.6(6.1)$ & $3.4(17.9)$ & $13.3(2.6)$ & $0.92(7.1)$ & $2.89(5.8)$ \\
90 & C & $3.7(20.6)$ & $5.1(36.3)$ & $12.3(24.5)$ & $0.88(5.8)$ & $3.18(7.1)$ \\
& D & $6.2(3.9)$ & $2.8(33.7)$ & $16.7(9.8)$ & $0.98(7.4)$ & $2.69(8.1)$ \\
\hline
\end{tabular}

$d_{u}=\frac{G_{f}}{f_{c}}$

Tables 2-4 show the average values of the compressive strength $(f c)$, as well as the respective estimated modulus of elasticity $(E)$, fracture energy $(G f)$ and ductility index $(d u)$. They present also the corresponding coefficients of variation in brackets. Only one stone (schist) and two grouts have been considered for the 90 days testing $(C$ and $D)$ due to storage limitations.
Analyzing the results of the uniaxial compression tests, the similar behavior in terms of strength for products $A$ and $B$ is evident, as is their difference in respect to the other two grouts. Also, the high compressive strength obtained by these two products is noted, especially for yellow granite and limestone, as well as high modulus of elasticity (from 15 to $20 \mathrm{GPa}$ ) compared to values from 3 to $7 \mathrm{GPa}$ for $D$ and from 2 to $4 \mathrm{GPa}$ for $C$. The following aspects are also to be noted: (a) Product $C$ has relatively low strength, particularly for yellow granite and limestone; (b) The observed values appear to be in agreement with those obtained in the compressive tests of the grout by itself, with higher values for $B$, and slightly lower values for $A, D$, and finally $C$, with the lowest values; (c) In general, injections using yellow granite and limestone as substrates provide higher strength when compared with the schist, even if this does not apply to all products; (d) An increase of strength of 33\% was obtained for products $C$ and $D$, from 28 to 90 days. The increase of strength of the grout alone, from 28 to 90 days, was $73 \%$ for $C$ and $16 \%$ for $D$, which indicates that there is no correspondence between the values in the isolated grout test and the tests in cylinders made of grout and stone.

There was a linear response up to approximately $60 \%$ of the ultimate load, especially in products $A$ and $B$, after which visible cracking started to occur. The behavior of the grout and stone cylinders seems to be governed by their capacity to absorb energy. The fracture energy is higher for materials $A$ and $B$, when compared to $C$ and $D$. Figs. 8 and 9 present dispersion graphs for the specimens of each type. The shaded area represents the envelope of the individual stress-strain diagrams for the different specimens. The graphs show results for schist for the four products (28 days for $A$ and $B$, and 90 days for $C$ and $D$ ). The graphs show that there is an apparent higher ductility in solutions $C$ and $D$, when compared with the other products. Comparing the values of fracture energy in compression resulting from these tests with the values for concrete in Model Code 90 [11], there seems to be some similarity in results, see Fig. 10. The fracture energy proposed in the code follows the equation:

$G_{f_{c}}=15+0.43 f_{c}-0.0036 f_{c}^{2}$

Table 3

Mechanical properties of compressive tests on specimens with yellow granite. Coefficients of variation (\%) in brackets.

\begin{tabular}{|c|c|c|c|c|c|c|}
\hline Age & Grout & $f_{\mathrm{c}}(\mathrm{MPa})$ & $E(\mathrm{GPa})$ & $G_{f}(\mathrm{~N} / \mathrm{mm})$ & $\varepsilon_{\text {peak }}(\%)$ & $d_{u}(\mathrm{~mm})$ \\
\hline \multirow[t]{4}{*}{28} & A & $23.5(6.1)$ & $17.3(36.9)$ & $32.0(9.4)$ & $0.60(22.7)$ & $1.37(13.7)$ \\
\hline & B & $21.7(0.3)$ & $16.4(44.1)$ & $33.4(2.8)$ & $0.51(3.4)$ & $1.54(2.5)$ \\
\hline & $\mathrm{C}$ & $0.9(1.7)$ & - & $5.4(10.1)$ & $1.21(8.1)$ & $5.41(11.8)$ \\
\hline & $\mathrm{D}$ & $7.4(6.0)$ & $5.9(33.4)$ & $27.9(5.0)$ & $1.46(3.0)$ & $3.81(8.5)$ \\
\hline
\end{tabular}


Table 4

Mechanical properties of compressive tests on specimens with limestone. Coefficients of variation (\%) in brackets.

\begin{tabular}{|c|c|c|c|c|c|c|}
\hline Age & Grout & $f_{\mathrm{c}}(\mathrm{MPa})$ & $E(\mathrm{GPa})$ & $G_{f}(\mathrm{~N} / \mathrm{mm})$ & $\varepsilon_{\text {peak }}(\%)$ & $d_{u}(\mathrm{~mm})$ \\
\hline \multirow[t]{4}{*}{28} & A & $18.3(3.0)$ & $17.8(49.3)$ & $19.5(3.8)$ & $0.32(0.1)$ & $1.07(7.0)$ \\
\hline & B & $20.9(7.7)$ & $14.9(27.5)$ & $23.5(15.8)$ & $0.35(6.0)$ & $1.13(16.6)$ \\
\hline & $\mathrm{C}$ & $1.1(5.3)$ & $2.5(38.5)$ & $2.2(29.0)$ & $0.53(23.4)$ & $1.95(25.2)$ \\
\hline & $\mathrm{D}$ & $4.0(8.0)$ & $3.5(39.4)$ & $13.8(18.5)$ & $1.13(0.4)$ & $3.42(10.6)$ \\
\hline
\end{tabular}

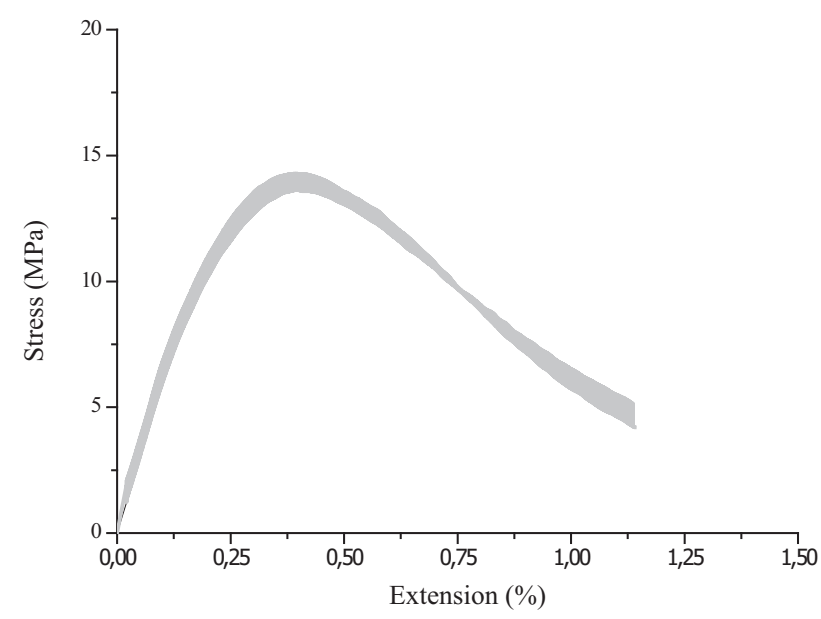

(a)

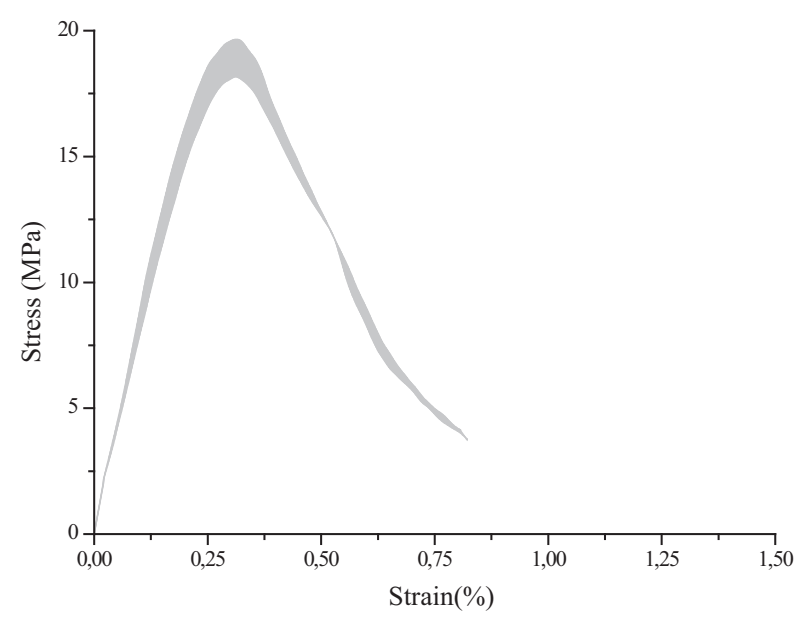

(b)

Fig. 8. Example of scatter in the stress-strain diagrams (28 days): (a) schist and grout $A$; (b) schist and grout $B$.

Table 5

Tensile strength in diametral tests on specimens on specimens with schist. Coefficients of variation (\%) in brackets.

\begin{tabular}{llll}
\hline Age & Grout & $f_{t}(\mathrm{MPa})$ & $f_{c} / f_{t}(\%)$ \\
\hline 28 & A & $1.4(1.2)$ & 10 \\
& B & $1.3(5.4)$ & 10 \\
& C & $0.3(10.6)$ & 15 \\
& D & $0.6(7.0)$ & 13 \\
90 & C & $0.6(19.5)$ & 16 \\
& D & $0.7(6.0)$ & 11 \\
\hline
\end{tabular}

This expression is valid for concrete with values of compressive strength between 12 and $80 \mathrm{MPa}$. The results with schist and product $C$ at 28 days appear to deviate from the values for concrete, as well as the values obtained in cylinders with granite and grout $D$, also at 28 days. For the ductility index, Model Code 90 (CEB-FIP, 1993) proposes an average value of $0.68 \mathrm{~mm}$ for concrete with a maximum of $1.6 \mathrm{~mm}$ when $f c<12 \mathrm{MPa}$ and a minimum of $0.33 \mathrm{~mm}$ for $f c>80 \mathrm{MPa}$. Again, products $C$ and $D$ seem not to fit the model proposed for concrete, see Fig. 11.

Standard EN 12390-6 [13] defines the process of determining the tensile strength by diametral compression (or indirect tension). The tensile strength of the specimens with breaking force $F$, height of the specimen $l$, and diameter of the specimen $d$ is given by:

$f_{t}=\frac{2 F}{\pi \times l \times d}$

Tables 5-7 show the average values of the tensile strength $\left(f_{t}\right)$, as well as the ratio between compressive and tensile strengths. The highest values are obtained once again for products $A$ and $B$. The results show also that some correlation exists between the results obtained in the compression tests and the indirect tension tests. The ratio between compressive and tensile strengths is around $10 \%$ for products $A$ and $B$, and is around $14 \%$ for products $C$ and $D$.

\subsection{Bond strength characterization}

One of the most important requirements of grout injection is the bond strength to the substrate. This is because the binding mortar/support is usually the weakest mechanical link, which controls the strength of masonry and its durability. Researches on the bond between stone and grout interfaces have been made by Adami and Vintzileou [1], Perret [27], Toumbakari [31], Miltiadou [23] and Figueiredo [17], using prismatic and cylindrical test pieces. No standards are available to stipulate the specimens and the preparation of the samples.

Here, the bond between stone and grout is characterized using pullout tests, providing the maximum tensile force applied in a circular area of grout with a diameter of approximately $48 \mathrm{~mm}$ applied to the stone substrate using a plastic mold. The three different stones used in the previous tests were considered (yellow granite, limestone and schist) with three different states of moisture content: (i) "wet" when the stones were placed in a humid chamber for at least two weeks with temperature conditions of $20{ }^{\circ} \mathrm{C} \pm 2{ }^{\circ} \mathrm{C}$ and relative humidity of $\approx 95 \%$; (ii) "dry" when the specimens were placed inside the laboratory at open air; (iii) "saturated" when pieces were submerged in water for $24 \mathrm{~h}$. In the case of schist, it was not possible to prepare the specimens with saturated stone, because the plastic molds could not be properly bonded.

The samples were tested at 28 and 90 days of age and the bond stress $\left(f_{d}\right)$ is the ratio of the force obtained $\left(F_{t}\right)$ and the initial section area of the grout specimen $(A)$. The tests were performed using displacement control at a rate of $2 \mu \mathrm{m} / \mathrm{s}$, see Fig. 12 . 


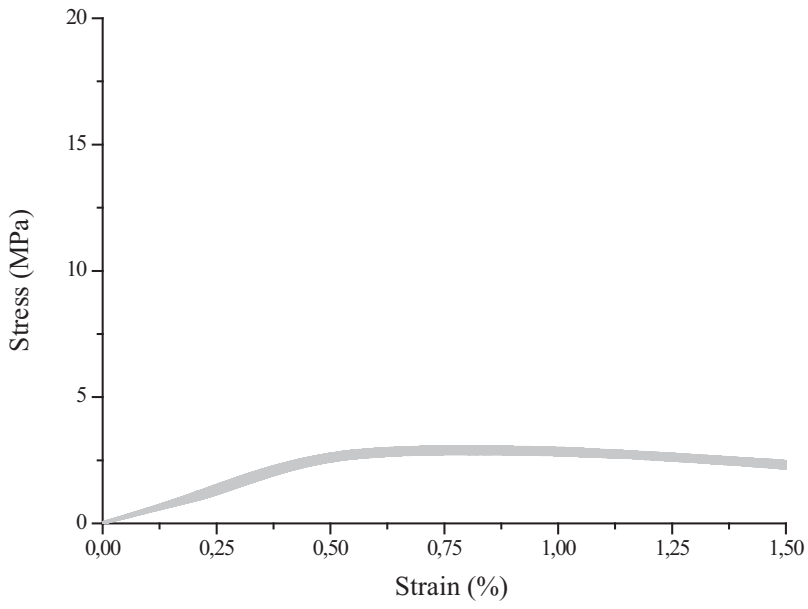

(a)

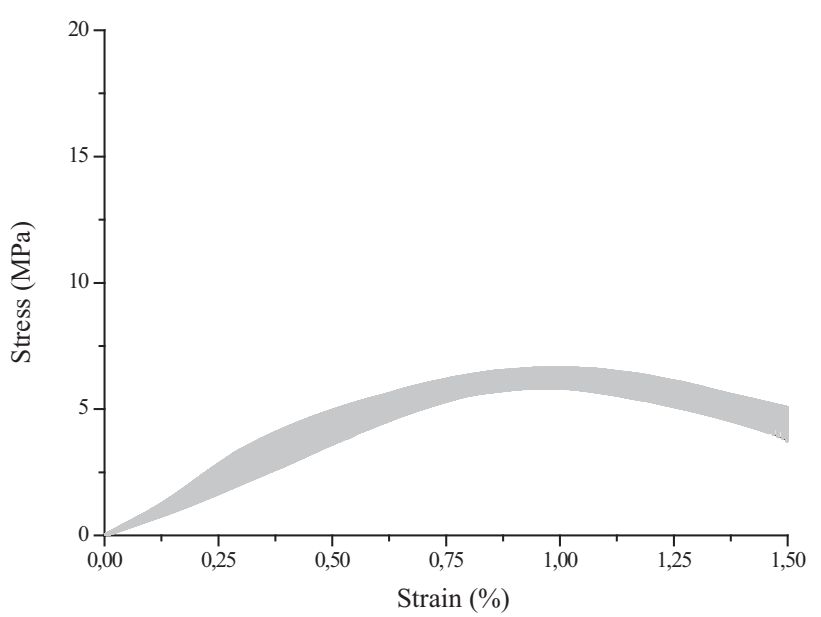

(b)

Fig. 9. Example of scatter in the stress-strain diagrams (90 days): (a) schist and grout $C$; (b) schist and grout $D$.

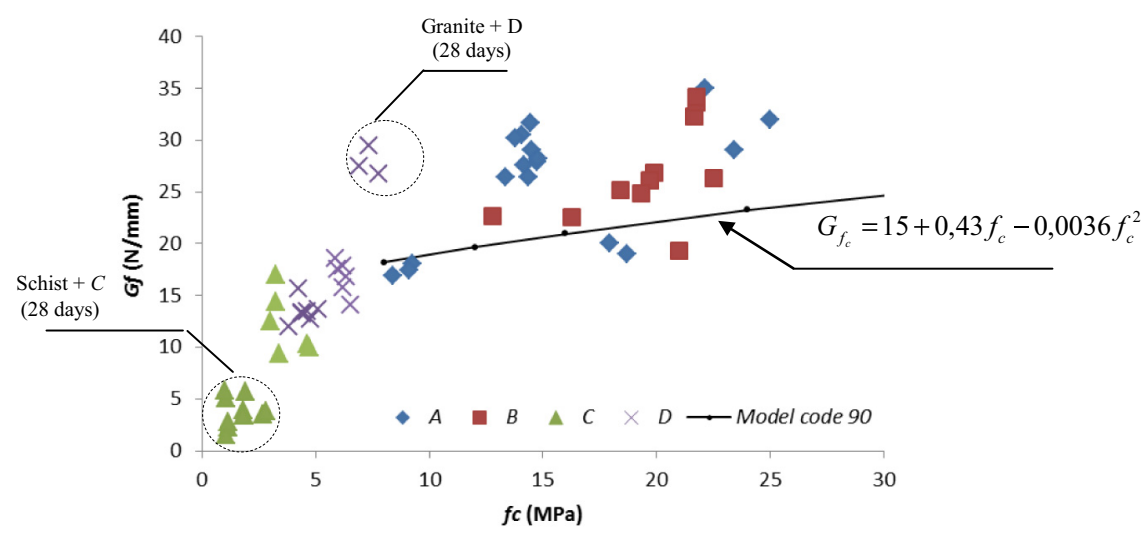

Fig. 10. Relationship between compressive strength $(f c)$ and fracture energy (Gf).

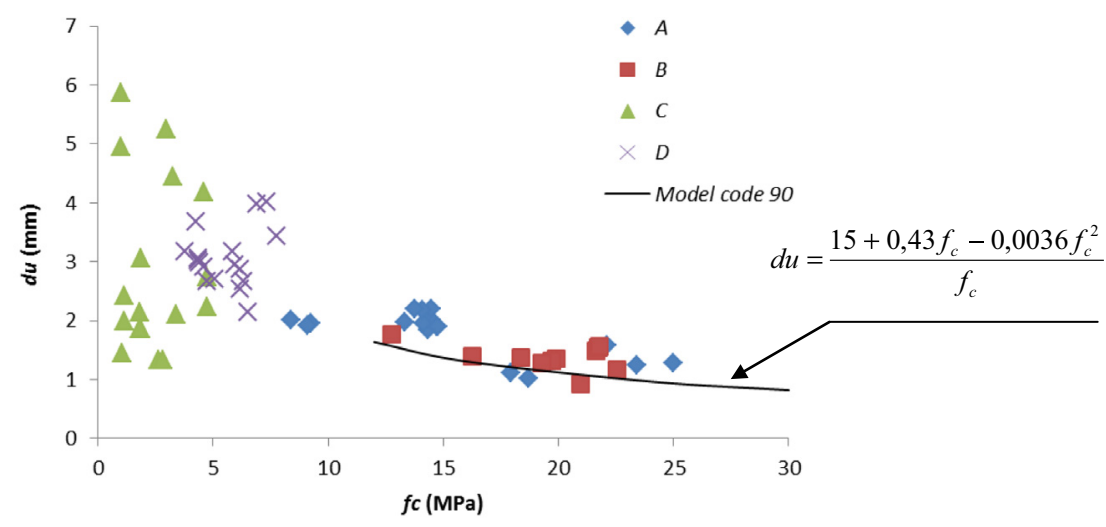

Fig. 11. Relationship between compressive strength and the ductility index.

Table 6

Tensile strength in diametral tests on specimens with yellow granite. Coefficients of variation (\%) in brackets.

\begin{tabular}{llll}
\hline Age & Grout & $f_{t}(\mathrm{MPa})$ & $f_{c} / f_{t}(\%)$ \\
\hline 28 & A & $2.1(4.7)$ & 9 \\
& B & $2.2(8.9)$ & 10 \\
& C & $0.1(9.8)$ & 14 \\
& D & $0.9(10.6)$ & 12
\end{tabular}

Table 7

Tensile strength in diametral tests on specimens with limestone. Coefficients of variation (\%) in brackets.

\begin{tabular}{llll}
\hline Age & Grout & $f_{t}(\mathrm{MPa})$ & $f_{C} / f_{t}(\%)$ \\
\hline 28 & A & $1.6(9.4)$ & 9 \\
& B & $2.0(7.2)$ & 10 \\
& C & $0.1(5.7)$ & 14 \\
& D & $0.6(9.6)$ & 15
\end{tabular}




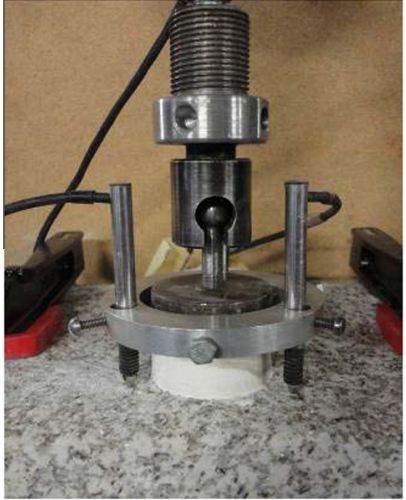

Fig. 12. Test setup.

$f_{d}=\frac{F_{t}}{A}$

In Fig. 13 the tensile bond strength results for yellow granite are graphically presented. The results indicate that the highest bond is obtained for granite in the "wet" state, when compared with those obtained in "dry" and "saturated" pieces. For the yellow granite, the maximum bond was obtained for all grouts in the "wet" state, with a bond strength of $1.26 \mathrm{MPa}$ obtained at 90 days of age for Product A. Products $C$ and $D$ presented values near $0.7 \mathrm{MPa}$ in the "dry" state at 90 days of age and poor results were obtained in granite both in the "wet" and the "saturated" state. The lowest bond strength value obtained was with granite saturated with $0.23 \mathrm{MPa}$.
Table 8

Qualitative classification of the four commercial grouts based on tests performed.

\begin{tabular}{llllll}
\hline & & $\mathrm{A}$ & $\mathrm{B}$ & $\mathrm{C}$ & $\mathrm{D}$ \\
\hline Fluidity & $10^{\circ} \mathrm{C}$ & + & ++ & - & + \\
& $20^{\circ} \mathrm{C}$ & + & + & \pm & ++ \\
& $30^{\circ} \mathrm{C}$ & ++ & ++ & - & ++ \\
Bleeding & & \pm & ++ & + & + \\
Injectability & Schist & ++ & ++ & + & ++ \\
& & & & + & \\
& Granite & + & + & \pm & ++ \\
& Limestone & \pm & ++ & + & ++ \\
Compression strength of grout & 28 days & ++ & ++ & \pm & + \\
Compression strength of grout/stone & Schist & ++ & ++ & \pm & + \\
$\quad$ (28 days) & Granite & ++ & ++ & \pm & + \\
Bond strength in "wet" & Limestone & ++ & ++ & \pm & + \\
Stone & Schist & ++ & + & - & \pm \\
(28 days) & Granite & ++ & \pm & - & \pm \\
& Limestone & ++ & - & - & \pm
\end{tabular}

Observations: Product $D$ requires constant stirring, because it has a tendency to segregate.

The best is indicated by "++", acceptable is indicate by " \pm " and "-_ indicates inappropriate.

In limestone, the bond strength is significantly worse. The test could not be performed in the majority of the samples, because the detachment of the grout occurred prior to it being tested. For schist the bond strength obtained is below those for granite, although grout $A$ had satisfactory results too, see [21]. In conclusion, product $A$ seems to have a better and uniform behavior, when compared to the other grouts and when tested in the three stones, even with different moisture contents.

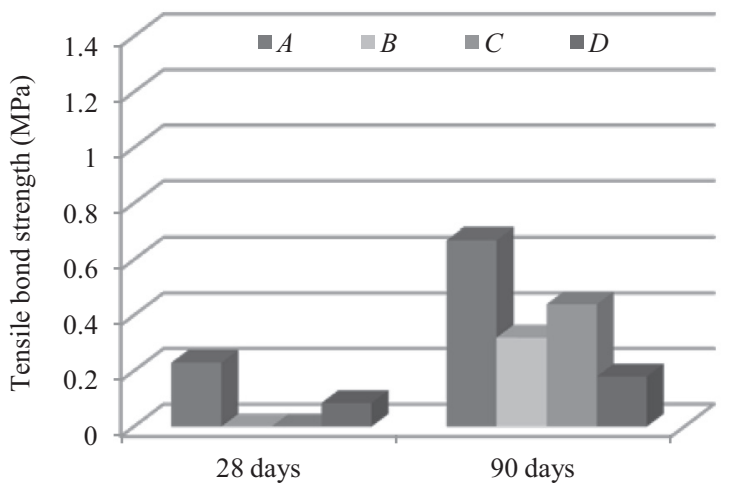

(b)

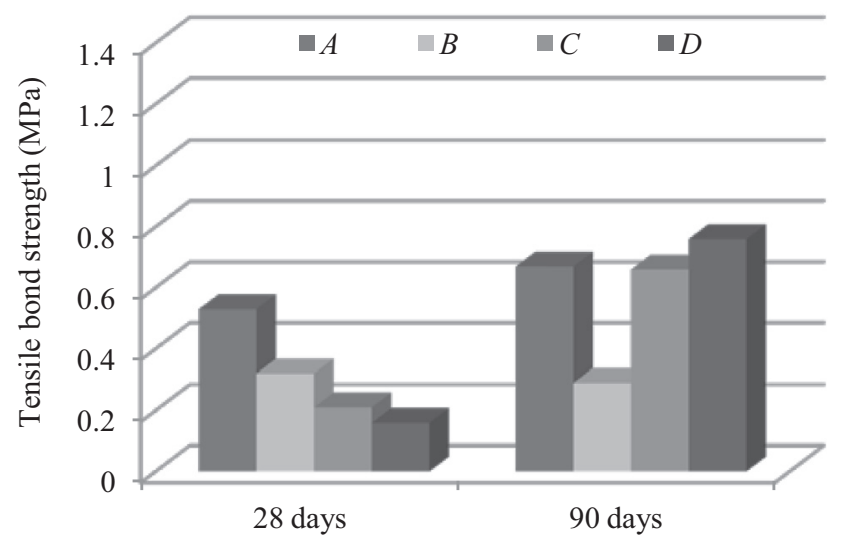

(c)

Fig. 13. Bond results in for yellow granite: (a) "wet"; (b) "saturated"; (c) "dry". 


\section{Conclusions}

The experimental campaign in the present paper considered four commercially available lime based grouts for consolidation of masonry structures. The selected products presented very different characteristics, both in terms of measurable properties using selected tests, as well as in terms of color, texture and workability.

For the tests performed in the laboratory significant differences were obtained between the products evaluated, both in terms of fluidity, mechanical properties or sensitivity to stone type of the substrate, humidity and temperature conditions. In particular, it is noted that the use of wet stone substrate severely deteriorates the bond strength and that very low bond was found in the presence of a limestone substrate. Here, the aim was a comparative analysis between the available grouts, without an individual classification or the definition of minimum requirements. The obtained results allow to better select grouts and define technical specifications.

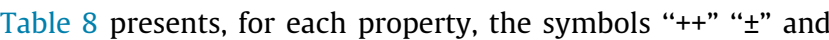
"-_, for the best, acceptable and inappropriate result. It is noted that: (a) the highest strength of the grouts is not the most relevant property and it is not necessarily beneficial for the masonry behavior, even if this also provides the highest strength in the stone and inject grout cylinders; (b) most procedures adopted are not standardized, so the results must be accepted with some caution.

\section{References}

[1] C.E. Adami, E. Vintzileou, Interventions to historic masonries: Investigation of the bond mechanism between stones or bricks and grouts, Mater. Struct. 41 (2) (2008) 255-267.

[2] ASTM C469/C469M-10, Standard Test Method for Static Modulus of Elasticity and Poisson's Ratio of Concrete in Compression, 2010.

[3] ASTM C940-10a, Standard Test Method for Expansion and Bleeding of Freshly Mixed Grouts for Preplaced-Aggregate Concrete in the Laboratory, 2010.

[4] L. Baltazar, F. Henriques, F. Jorne, Optimisation of flow behaviour and stability of superplasticized fresh hydraulic lime grouts through design of experiments, Constr. Build. Mater. 35 (2012) 838-845.

[5] L. Baltazar, F. Henriques, F. Jorne, M. Cidade, Combined effect of superplasticizer, silica fume and temperature in the performance of natural hydraulic lime grouts, Constr. Build. Mater. 50 (2014) 584-597.

[6] L. Baltazar, F. Henriques, Rheology of grouts for masonry injection, Key Engineering Materials (volume 624), available in http://www.scientific.net/ kem.624.283, 2014.

[7] L. Binda, G. Baronio, C. Tiraboschi, C. Tedeschi, Experimental research for the choice of adequate materials for the reconstruction of the Cathedral of Noto, Constr. Build. Mater. 17 (2003) 629-639.

[8] L. Binda, A. Saisi, C. Tedeschi, Compatibility of materials used for repair of masonry buildings: research and applications, Fracture and Failure of Natura Building Stones - Applications in the Restoration of Ancient Monuments, Part I, Stavros K. Kourkoulis Editor, Elsevier, 2006.

[9] A. Bras, F. Henriques, Natural hydraulic lime based grouts - the selection of grout injection parameters for masonry consolidation, Constr. Build. Mater. 26 (2012) 135-144

[10] A. Bras, F. Henriques, M. Cidade, Effect of environmental temperature and fly ash addition in hydraulic lime grout behaviour, Constr. Build. Mater. 24 (2010) 1511-1517.

[11] CEB-FIP model code 90 (1993) Design Code, Comite euro-international du beton, Thomas Telford.
[12] E 397 (1993) Concrete. Determination of the elasticity modulus in compression, LNEC (in Portuguese).

[13] EN 12390-6 (2011) Testing hardened concrete. Part 6: Tensile splitting strength of test specimens.

[14] EN 196-1 (2006) Methods of testing cement. Determination of strength.

[15] EN 445 (2007) Grout for prestressing tendons. Test methods.

[16] EN 447 (2007) Grout for prestressing tendons. Basic requirements.

[17] Figueiredo, A., Injection Grouts for Ancient Masonry - Adherence study, available in https://fenix.tecnico.ulisboa.pt/, 2013.

[18] D. Jansen, S. Shah, Effect of length on compressive strain softening of concrete, J. Eng. Mater. 123 (1) (1997) 25-35.

[19] A. Kalagri, A. Miltiadou-Fezans, E. Vintzileou, Design and evaluation of hydraulic lime grouts for the strengthening of stone masonry historic structures, Mater. Struct. 43 (2010) 1135-1146.

[20] P.B. Lourenço, L.F. Ramos, K.J. Krakowiak, Cathedral of Porto, Portugal: Conservation works 2003-2008, in: Proceedings of 11th Canadian Masonry Symposium, Toronto, Ontario, Canada, CD-ROM, 2009, 20p.

[21] E. Luso, Experimental analysis of lime based grouts for the ancient masonry injections (PhD thesis), University of Minho, Portugal. Available from http:// hdl.handle.net/1822/23073, 2012.

[22] E. Luso, A. Monteiro, Study of the Influence of Adjuvant on Performance of Lime-based Grouts. $9^{\circ}$ Congresso Nacional de Mecânica Experimental, Aveiro, 15-17 de Outubro, 2014

[23] A. Miltiadou, Contribution à l'étude des coulis hydrauliques pour la réparation et le renforcement des structures et des monuments historiques en maconnerie Phd Tesis, Ecole nationale des ponts et chaussées, Paris, 1990.

[24] A. Miltiadou-Fezans, T. Tassios, Fluidity of hydraulic grouts for masonry strengthning, Mater. Struct. 45 (2012) 1817-1828.

[25] A. Miltiadou-Fezans, T. Tassios, Penetrability of hydraulic grouts, Mater. Struct. 46 (10) (2013) 1653-1671.

[26] A. Miltiadou-Fezans, E. Vintzileou, E. Papadopoulou, A. Kalagri, Mechanical properties of three-leaf stone masonry after grouting. in: Proc 5th Struct Analysis of Historical Constructions, New Delhi, 2006, pp. 785-792.

[27] S. Perret, Rôle du degré de saturation des sables fins à moyens sur leur injectabilité par des coulis de ciment microfin ( $\mathrm{PhD}$ thesis), Université de Sherbrooke (Québec) Canada, 2002.

[28] S. Perret, G. Ballivy, D. Palardy, R. Laporte, Formulation of high-performance cement grouts for the rehabilitation of heritage masonry structures, Third International Conference On Grouting and Grout Treatment, New Orleans, Louisiana, 2003.

[29] L. Schueremans, Probabilistic evaluation of structural unreinforced masonry (PhD thesis), Katholieke Universiteit Leuven, Belgium, 2001.

[30] R. Silva, Experimental characterization of masonry: strengthening and long term effects (Master thesis), University of Minho (in Portuguese), Portugal. Available from http://hdl.handle.net/1822/9036, 2008.

[31] E. Toumbakari, Lime-Pozzolan-Cement Grouts and their Structural Effects on Composite Masonry Walls, (PhD thesis), Katholieke Universiteit Leuven, Belgium, 2002

[32] E. Toumbakari, D. Van Gemert, T. Tassios, E. Vintzileou, Experimental investigation and analytical modelling of the effect of injection grouts on the structural behaviour of three-leaf masonry walls. in: 4th International Seminar on Structural Analysis of Historical Constructions, Padova, Italy, 2004, pp. 707717.

[33] M. Valluzi, Comportamento meccanico di murature consolidate con materiali e tecniche a base di balce (PhD thesis), Universita degli Studi di Trieste, Italy, 2000.

[34] F. Van Rickstal, Grout injection of masonry, scientific approach and modeling, Int. J. Restor. Build. Monuments 7 (34) (2001) 407-432.

[35] G. Vasconcelos, Experimental investigations on the mechanics of stone masonry: characterization of granites and behavior of ancient masonry shear walls (PhD thesis), University of Minho, Portugal. Available from http://hdl. handle.net/1822/17383, 2005.

[36] E. Vintzileou, Grouting of three-leaf stone masonry: types of grouts, mechanical properties of masonry before and after grouting, Struct. Anal. Historical Constr. 1 (2006) 41-58.

[37] E. Vintzileou, Three-leaf stone masonry in compression, before and after grouting: a review of literature, Int. J. Arch. Heritage 5 (2011) 513-538. Taylor \& Francis. 